\title{
ACTIVATION OF PROPLASMIN BY A FACTOR FROM MAMMALIAN TISSUE ${ }^{1,2}$
}

\author{
BY H. J. TAGNON 3 AND G. E. PALADE \\ (From the Sloan-Kettering Institute for Cancer Research and the Medical Department of \\ Memorial Hospital, New York City; and the Rockefeller Institute for \\ Medical Research, New York City)
}

(Received for publication August 1, 1949)

The proteolytic enzyme, plasmin, is found in normal plasma in an inactive form called plasminogen or fibrinolysin. In addition, plasma contains an inhibitor of plasmin which is probably identical with plasma antitrypsin (1). When plasma is shaken with certain organic solvents like chloroform and ether, the activity of the inhibitor is abolished and activation of plasminogen takes place, presumably by auto-catalysis (2). Shaking with chloroform or ether has been known for a long time to result in the production of proteolytic activity.

The activation of plasminogen after removal of the inhibitor is a slow process. Maximum activation of human plasma is usually obtained after 72 to 96 hours at room temperature $\left(25^{\circ} \mathrm{C}\right.$.). Dog plasma requires less time while beef plasma requires more time (1).

In contrast to the activation of plasminogen which occurs after removal of the plasmin inhibitor, the activation by means of streptokinase takes place rapidly even in the presence of plasmin inhibitor. Streptokinase is obtained from the cultures of certain strains of hemolytic streptococci; it appears to be an enzyme which catalyses the transformation of plasminogen into plasmin (2). Thus, the addition of an active preparation of streptokinase to normal human plasma results in the production of proteolytic activity in a matter of minutes at $37^{\circ} \mathrm{C}$. (2).

It has recently been observed that the active enzyme plasmin is occasionally found in the blood of patients with certain types of diseases (3) ; its presence in circulating blood may have serious

1 Supported by grants from the National Cancer Institute of the U. S. Public Health Service and from the Office on Naval Research.

2 Presented, in part, at the 41st Annual Meeting of the American Society for Clinical Investigation.

8 This work was done in part under the tenure of a fellowship from the Committee on Growth of the American Cancer Society. consequences for the patient, since the enzyme is able to digest fibrinogen and prothrombin (4) with resulting failure of the hemostatic mechanism. The presence of active enzyme in the circulating blood is easily detected by the observation of the phenomenon called fibrinolysis, characterized by the fact that the blood clot redissolves entirely within a few minutes or a few hours at $37^{\circ} \mathrm{C}$. This has been observed in cases of shock due to hemorrhage, burn, or trauma, and in other conditions not necessarily related to shock. Its occurrence in hemorrhagic shock is of bad prognostic significance and the rapid digestion of fibrinogen may lead to fatal failure of the hemostatic mechanism.

The two known mechanisms of elaboration of plasmin from proplasmin fail to explain the sudden appearance of active enzyme in the circulating blood of certain patients. Thus, chloroform activation of proplasmin is a slow process while the appearance of fibrinolysis may be quite sudden. On the other hand streptococcic or other types of infections have not been found in all patients showing fibrinolysis. The question of whether there is a physiological activator of proplasmin in the organism is unanswered.

Astrup and Permin $(5,6)$ have reported that aqueous extracts of certain tissues are able to activate plasminogen into plasmin. They found that the activator was associated with the particulate component of the extract (5). Their observations were confirmed by us ( 7$)$. It is conceivable that a tissue activator of proplasmin could explain the fibrinolysis observed in certain patients. The present work describes the method of preparation and the properties of this factor.

\section{MATERIAL AND METHODS}

Tissue extract: The lungs of freshly killed rats were forced through a $1 \mathrm{~mm}$. mesh. The pulp thus obtained was homogenized by means of an all glass tissue grinder 
and suspended in ten times its weight of ice-cold $30 \%$ sucrose solution. This suspension (homogenate) was then submitted to differential centrifugation in the cold according to the method of Claude (8) as modified by Hogeboom, Schneider and Palade (9). The sediments and supernates were labeled according to the nomenclature of these authors. The homogenate was first freed of cells and cell nuclei and the suspension thus obtained was labeled "extract." Fractionation of the extract yielded four different fractions: Supernate I, mitochondria fraction, Supernate II, microsomes fraction (Figure 1).

Plasminogen: As a source of plasminogen, the globulin fraction of human plasma obtained by dialysis against running tap water (temperature $4^{\circ}$ to $6^{\circ} \mathrm{C}$.) for three days was used. At the end of dialysis, the precipitate of globulin was dissolved in $\mathrm{M} / 100$ phosphate buffer in saline at $\mathrm{pH}$ 7.2. The final solution represented a ten times concentration as compared to the original plasma. On dissolving the globulin precipitate in saline buffer, a clot of fibrin formed which was removed on a glass rod and subsequent testing of the solution with thrombin showed that it was fibrinogen-free.

This solution of globulin is admittedly impure, but constitutes a good source of plasminogen (1).

It is well known that plasma globulin solutions, prepared by dialysis or otherwise, on incubation at room temperature or even at ice-box temperature, will occasionally develop fibrinolytic activity. For this reason, the globulin solutions used in these experiments were tested and only those showing no fibrinolytic activity over a period of four hours at $37^{\circ} \mathrm{C}$. were used, except when stated otherwise.

Fibrinogen: A fibrinogen solution was made from human plasma by the method of Ware, Guest and Seegers (10). The clottable nitrogen constituted $95 \%$ or more of the total nitrogen. The final concentration was adjusted to $0.2 \%$ of fibrinogen and to the desired $\mathrm{pH}$ by the addition of buffer solution before use ( $\mathrm{M} / 100$ phosphate buffer in $0.85 \%$ sodium chloride solution).

Thrombin: A greparation of globulin obtained from rabbit plasma was used as a source of thrombin (Lederle clotting globulin).

Buffer solutions: Phosphate buffer solutions were used. A dilute buffer ( $M / 100$ in $0.85 \%$ sodium chloride solution) was used when subsequent experimental changes of $\mathrm{pH}$ were contemplated. A concentrated buffer ( $M / 15$ in water) was used in all other cases.

The $\mathrm{pH}$ was determined by means of the glass electrode.

Determination of proteolytic activity: This was done by measuring the time of dissolution of a clot obtained by diluting $0.2 \mathrm{cc}$. of the standard solution of fibrinogen, after addition of the material to be tested, to a total volume of $1 \mathrm{cc}$. by addition of the appropriate buffer solution. The solution was then clotted by rotating a glass rod previously immersed to a height of $0.5 \mathrm{~cm}$. in the thrombin solution. The reaction was carried out in test tubes $(70 \times 10 \mathrm{~mm}$.), made of Pyrex glass and immersed in a constant temperature water bath. Time was counted from the mixing of the reagent to the disappearance of the shreds of fibrin.

All material was prepared in sufficient quantities for a great number of determinations and was quick-frozen and kept at $-15^{\circ} \mathrm{C}$. without loss of activity for two to four weeks.

\section{RESULTS}

\section{Effect of lung extract on plasminogen}

When the fibrinogen solution was mixed with either the globulin solution (containing plasminogen) or the lung extract, and thrombin added, a clot resulted which did not dissolve during the period of observation (four hours). However, when both the globulin solution and the lung extract were incorporated into the clot, dissolution occurred in a short time (Table I, tube 2 ).

TABLE I

Fibrinolytic activity of lung extract in the presence of plasma globulin solution

\begin{tabular}{|c|c|c|c|c|}
\hline \multirow{2}{*}{$\begin{array}{l}\text { Tube } \\
\text { No. }\end{array}$} & \multicolumn{3}{|c|}{ Reagents in cc. } & \multirow{2}{*}{$\begin{array}{c}\text { Dissolution } \\
\text { time }\end{array}$} \\
\hline & $\begin{array}{l}\text { Globulin } \\
\text { solution }\end{array}$ & $\begin{array}{c}\text { Lung } \\
\text { extract }\end{array}$ & $\begin{array}{c}\text { Fibrinogen- } \\
\text { thrombin }\end{array}$ & \\
\hline $\begin{array}{l}1 \\
2 \\
3 \\
4\end{array}$ & $\begin{array}{l}0.1 \\
0.1 \\
0.1 \\
0.0\end{array}$ & $\begin{array}{l}0.0 \\
0.1 \\
0.3 \\
0.1\end{array}$ & $\begin{array}{l}0.2 \\
0.2 \\
0.2 \\
0.2\end{array}$ & $\begin{array}{c}\text { min. } \\
240+ \\
17 \\
29 \\
240+\end{array}$ \\
\hline
\end{tabular}

Total volume in each tube brought to $1 \mathrm{cc}$. by the addition of $M / 15$ buffer.

$\mathrm{pH}, 7.1$; temperature, $37^{\circ} \mathrm{C}$.

Amount of sucrose in solution constant in all tubes.

The same table shows that when the quantity of lung extract added to the mixture of globulin and fibrinogen solutions increased, the time of dissolution of the clot was increased (Table I, tubes 2 and 3 ). This suggested that the extract contained an inhibitor of the reaction. An attempt was therefore made to separate the inhibitor from the activator.

\section{Effect of fractions from lung extract on plas- minogen}

Fractions obtained by differential centrifugation of the lung extract (Figure 1) were tested (Table II). In this experiment the volume of each fraction corresponded to the volume of the whole extract and the concentration of sucrose was kept constant in each test tube. Corresponding amounts 


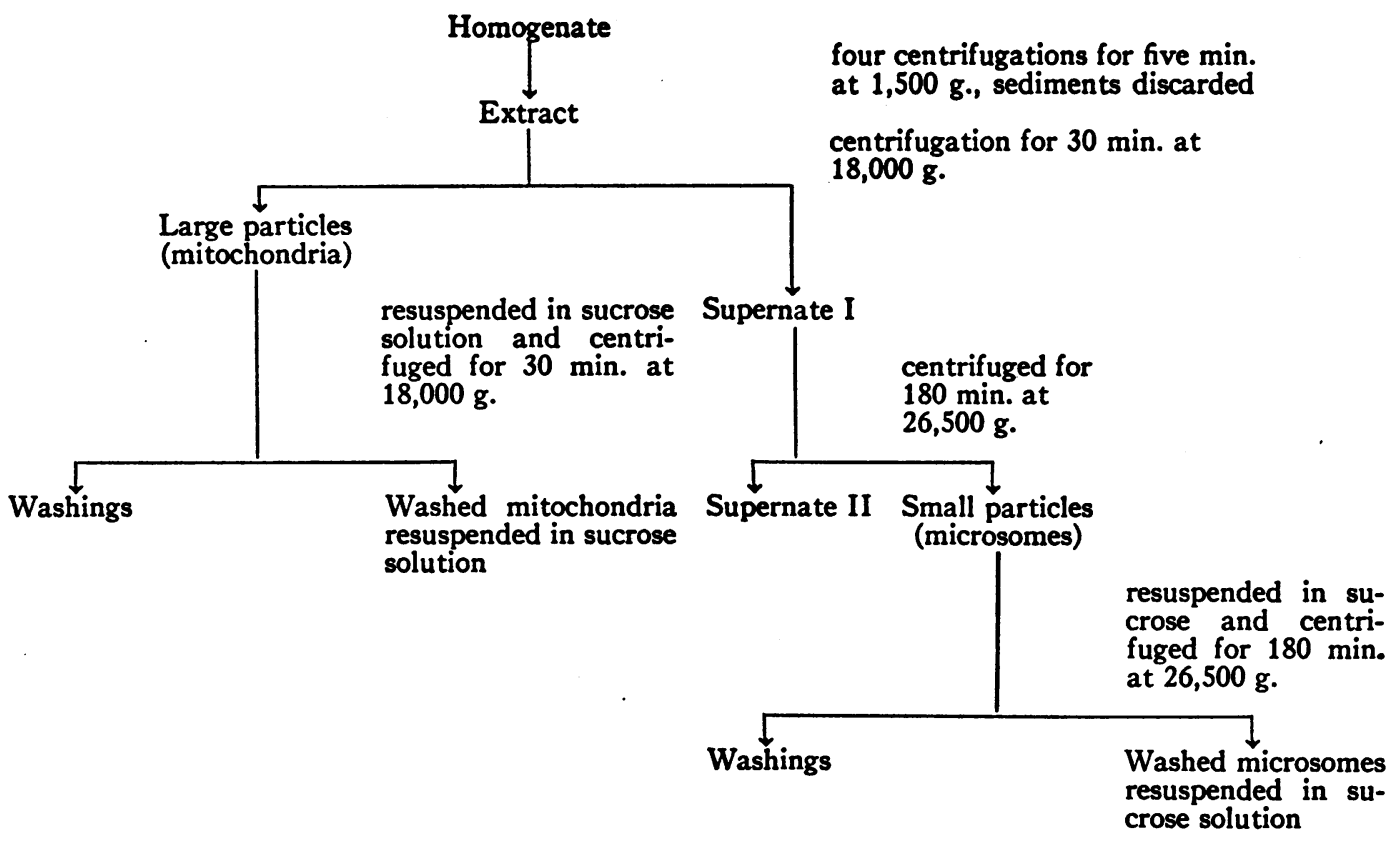

Fig. 1. Fractionation of Rat Lung

of each particulate fraction and of each supernate were added to the mixture of globulin solution and fibrinogen solution. Thrombin was added and the time of dissolution of the clot measured. The results show that the activity of the lung extract was found in the fraction of mitochondria and of microsomes. The activity was also present

TABLE II

Action of lung fractions on plasminogen*

\begin{tabular}{|c|c|c|c|c|c|c|}
\hline \multirow{2}{*}{$\begin{array}{l}\text { Tube } \\
\text { No. }\end{array}$} & \multicolumn{5}{|c|}{ Reagents in cc. $\dagger$} & \multirow{2}{*}{$\begin{array}{l}\text { Disso- } \\
\text { lution } \\
\text { of clot }\end{array}$} \\
\hline & $\begin{array}{l}\text { Total } \\
\text { extract }\end{array}$ & $\begin{array}{c}\text { Mito- } \\
\text { chondria }\end{array}$ & $\begin{array}{l}\text { Super- } \\
\text { nate I }\end{array}$ & $\begin{array}{l}\text { Micro- } \\
\text { somes }\end{array}$ & $\begin{array}{l}\text { Super- } \\
\text { nate II }\end{array}$ & \\
\hline $\begin{array}{r}1 \\
2 \\
3 \\
4 \\
5 \\
6 \\
7 \\
8 \\
9 \\
10\end{array}$ & $\begin{array}{l}.1 \\
.3\end{array}$ & $\begin{array}{l}.1 \\
.3\end{array}$ & $\begin{array}{l}.1 \\
.3\end{array}$ & $\begin{array}{l}.1 \\
.3\end{array}$ & $\begin{array}{l}.1 \\
.3\end{array}$ & $\begin{array}{c}\text { min. } \\
15 \\
27 \\
30 \\
35 \\
16 \\
26 \\
11 \\
9 \\
120+ \\
120+\end{array}$ \\
\hline
\end{tabular}

* All fractions were suspended in a volume equal to that of the original extract.

† Fibrinogen $0.2 \mathrm{cc}$. + globulin solution $0.1 \mathrm{cc}$. $+\mathrm{M} / 15$ phosphate buffer to make a total volume of $1 \mathrm{cc}$. Thrombin (on glass rod) added to each tube.

$\mathrm{pH}, 7.2$; temperature, $37^{\circ} \mathrm{C}$.

Control experiments: ( 1 ) Same as in table with omission of globulin solution: no dissolution in four hrs. (2) Same as in table with omission of fractions of tissue: no dissolution in four hrs. in Supernate I but completely absent from Supernate II.

This indicated that the activity of Supernate I resided in the microsomes. Furthermore, the phenomenon of inhibition observed when increasing amounts of whole extracts were used was also observed when Supernate I and to a lesser degree the mitochondria were used. It was not observed when the microsome fraction was used. Supernate II added in any amount to the mixture of globulin and fibrinogen did not promote fibrinolysis. This fact and the absence of inhibitor in the microsome fraction indicated that the inhibitor material present in Supernate I was apparently entirely separated in Supernate II, and that none was present in the microsome fraction.

Three similar fractionation experiments of rat lung tissue were carried out. In each experiment it was found that the activity was present in the two particulate fractions and was always absent from Supernate II. The amount of activity, as measured by the time of dissolution of the clot of fibrin to which the globulin solution was added, was equal in the mitochondria and the microsome fraction in two instances; in the other, the microsome fraction was slightly more active than the mitochondria fraction. Inhibitor material was always absent from the microsome fraction, while 
some inhibitory action was observed with the mitochondria fraction in one experiment.

The microsome fraction was therefore selected as the material best suited for a study of the properties of the activator.

\section{Properties of the activator present in the micro- some fraction of the lung extract}

From the experimental evidence presented in the previous paragraph, it was provisionally concluded that the globulin solution contained an inactive precursor of plasmin, which was activated by a factor present in the microsome fraction of the lung extract. The following experiments were performed to study the properties of this factor and the nature of its reaction with plasminogen.

1. Effect of incubation: When a mixture of globulin solution and microsomes was incubated at $37^{\circ}$ C. proteolytic activity appeared and gradually increased (Figure 2).

In the preceding experiment, the globulin solution alone, as stated under Methods, had no fibrinolytic activity over a period of four hours. However, as shown in the following experiment, the activating effect of the microsome fraction

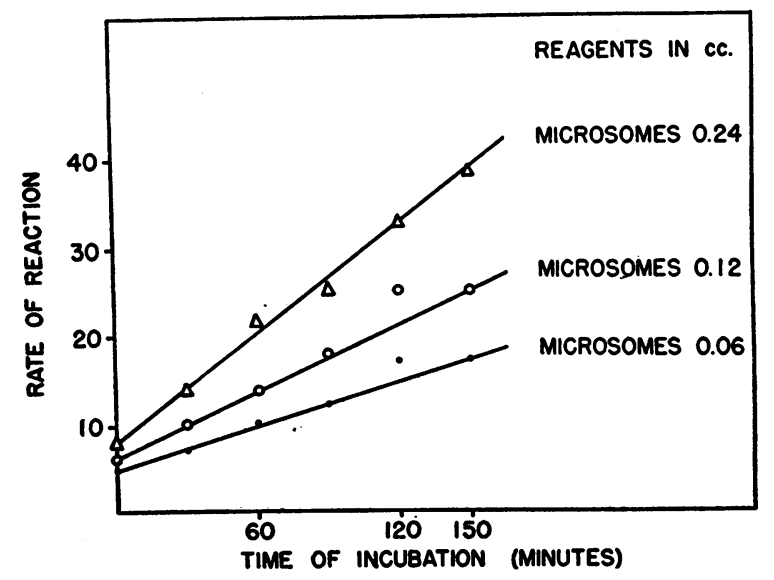

Fig. 2. Effect of Incubation on Development of Proteolytic Activity

Each inscription represents the proteolytic activity developed on incubation at $37^{\circ} \mathrm{C}$. of three mixtures each made of $0.1 \mathrm{cc}$. globulin solution; $0.06 \mathrm{cc}$., $0.12 \mathrm{cc}$. and 0.24 cc., respectively, of microsomes suspension; and enough $M / 100$ phosphate buffer in physiological saline at pH 7.2 to make a total volume of $1 \mathrm{cc}$. Rate of reaction represents $\frac{1}{T} \times 100, T$ being the time of dissolution of the clot of fibrin. could be demonstrated even on a globulin solution having some fibrinolytic activity. The addition of this globulin solution to fibrinogen without microsomes produced lysis of the fibrin clot in 185 minutes and on incubation of the globulin solution at $37^{\circ} \mathrm{C}$. the fibrinolytic activity did not increase. However, when microsomes were added to the mixture of fibrinogen and globulin solution, the time of dissolution of the clot was 11 minutes and on incubation of the mixture of fibrinogen and globulin, increasing proteolytic activity developed as shown by the increased fibrinolysis.

2. Effect of varying the proportion of globulin solution to microsome fraction: In this experiment three mixtures were incubated at $37^{\circ} \mathrm{C}$. each containing the same amount of globulin solution, but different amounts of microsome fraction. At intervals, an aliquot was taken from each mixture and tested for proteolytic activity in the usual manner by the addition of fibrinogen and thrombin and recording the time of dissolution of the clot. As shown in Figure 2, the proteolytic activity increased with increasing amounts of microsome fraction in each mixture.

In the following experiment six tubes were prepared, each containing the same amount of microsome fraction but increasing amounts of globulin fraction. Fibrinogen and thrombin were added to each tube and the time of dissolution of the clot (at $37^{\circ}$ C.) recorded. The results (Table III) show that the proteolytic activity in each tube was identical with the exception of the last tube containing the largest amount of globulin, which showed less activity.

In the next experiment (Figure 3) three identical mixtures of microsome fraction and globulin

TABLE III

Effect of microsomes on varying quantities of globulin solution

\begin{tabular}{c|c|c|c|c}
\hline & \multicolumn{3}{|c|}{ Reagents in cc. } & \multirow{2}{*}{$\begin{array}{c}\text { Tube } \\
\text { No. }\end{array}$} \\
\cline { 2 - 3 } & $\begin{array}{c}\text { Missolution } \\
\text { Mime } \\
\text { somes }\end{array}$ & $\begin{array}{c}\text { Globulin } \\
\text { solution }\end{array}$ & $\begin{array}{c}\text { Fibrinogen- } \\
\text { thrombin }\end{array}$ & \\
\hline & & & & min. \\
1 & 0.1 & 0.02 & 0.2 & 19 \\
2 & 0.1 & 0.04 & 0.2 & 19 \\
3 & 0.1 & 0.08 & 0.2 & 19 \\
4 & 0.1 & 0.1 & 0.2 & 19 \\
5 & 0.1 & 0.2 & 0.2 & 19 \\
6 & 0.1 & 0.3 & 0.2 & 24 \\
\hline
\end{tabular}

Temperature, $37^{\circ} \mathrm{C}$. $\mathrm{M} / 15$ phosphate buffer, $\mathrm{pH}$ 7.2, added to make total volume of $1 \mathrm{cc}$. in each tube. 


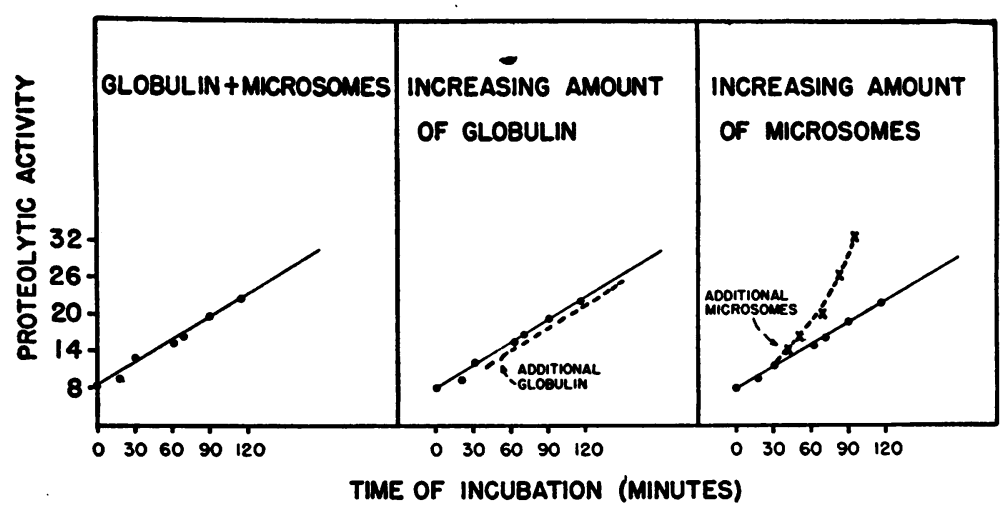

Fig. 3. Effect of the Addition of Globulin Solution or Microsomes Suspension on the Proteolytic Activity

Three identical mixtures were incubated at $37^{\circ} \mathrm{C}$., each made of the following reagents: microsomes $0.7 \mathrm{cc}$., globulin solution $0.7 \mathrm{cc} ., \mathrm{M} / 15$ phosphate buffer at $\mathrm{pH} 7.2: 3.5 \mathrm{cc}$. At intervals, $0.7 \mathrm{cc}$. was taken from the mixture and the proteolytic activity tested. At the time indicated the following addition was made to each mixture, respectively: $0.4 \mathrm{cc}$. buffer, $0.4 \mathrm{cc}$. microsomes, $0.4 \mathrm{cc}$. globulin solution. Proteolytic activity was subsequently estimated in the usual fashion. Proteolytic activity is expressed as $\frac{1}{T} \times 100, T$ being the time of dissolution of the clot.

solution were incubated at $37^{\circ} \mathrm{C}$. At intervals, aliquot samples were taken from each mixture and the proteolytic activity determined. After 35 minutes, an additional amount of globulin was added to the second mixture, an additional amount of microsome fraction to the third mixture and an equivalent volume of buffer solution to the first (control) mixture; aliquot samples were again taken at intervals and the proteolytic activity estimated. The results show (Figure 3 ) that the addition of globulin solution did not modify the rate of formation of proteolytic activity while the addition of microsomes definitely accelerated this rate.

3. Effect of temperature on microsomes and globulin solution: The microsome fraction was incubated at $37^{\circ} \mathrm{C}$. and $53^{\circ} \mathrm{C}$. for $35 \mathrm{~min}$. and 120 min. Following each period of incubation, an aliquot was tested. Globulin solution was similarly incubated at $37^{\circ} \mathrm{C}$. and $56^{\circ} \mathrm{C}$. for $35 \mathrm{~min}$. and $120 \mathrm{~min}$., following which an aliquot was removed, fresh microsome fraction was added and the mixture tested for dissolution potency.

Table IV shows that incubation of either globulin or microsomes at $37^{\circ} \mathrm{C}$. for $35 \mathrm{~min}$. resulted in no loss of proteolytic activity, while if the incubation period was prolonged to $120 \mathrm{~min}$., there was a slight loss of activity. At $56^{\circ} \mathrm{C}$., there was a definite loss of activity in $35 \mathrm{~min}$. and greater loss in $120 \mathrm{~min}$.

At $100^{\circ} \mathrm{C}$. the globulin solution and the microsome fraction lost activity completely in five min.

4. Effect of $p H$ : A series of test tubes was prepared, each containing the same amount of micro-

TABLE IV

Effect of temperature on microsomes and globulin solution*

35 min. incubation at $37^{\circ} \mathrm{C} . \begin{cases}\text { microsomes } & 16 \\ \text { globulin } & 16\end{cases}$

$120 \mathrm{~min}$. incubation at $37^{\circ} \mathrm{C}$. microsomes 19

$35 \mathrm{~min}$. incubation at $56^{\circ} \mathrm{C}$. microsomes 32

$120 \mathrm{~min}$. incubation at $56^{\circ} \mathrm{C}$. microsomes 36

5 min. incubation at
boiling $\mathrm{T}^{\circ}$$\quad \begin{cases}\text { microsomes } & 120+ \\ \text { globulin } & 120+\end{cases}$

Control (non-incubated reagents) 16

* In each test tube, the following mixture was prepared and the time of dissolution of the clot recorded. The microsomes and globulin solution used were incubated separately prior to the preparation of the mixture as indicated below:

Microsomes 0.1 cc. + globulin 0.1 cc. + M/15 buffer $0.6 \mathrm{cc}$., $\mathrm{pH} 7.2$, + fibrinogen $0.2 \mathrm{cc}$. + thrombin. Temperature $37^{\circ} \mathrm{C}$. 


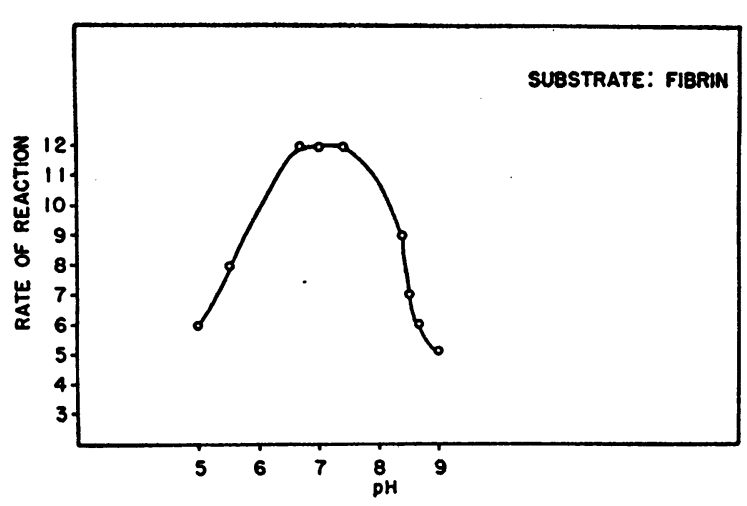

Fig. 4. Effect of pH on Proteolytic Activity (Explanations in text)

some fraction and globulin solution in $M / 100$ phosphate buffer. Suitable amounts of $0.01 \mathrm{~N}$ $\mathrm{HCl}$ and $0.01 N \mathrm{NaOH}$ were added to each tube to bring the $\mathrm{pH}$ to the desired level, and the volume in each tube was kept constant by the addition of appropriate amounts of physiological saline. After incubating the tube for one-half hour, every sample was brought to approximately $\mathrm{pH} 7.2$ by the addition of either $0.01 \mathrm{~N} \mathrm{HCl}$ or $\mathrm{NaOH}$ and 0.5 cc. $\mathrm{M} / 15$ phosphate buffer at $\mathrm{pH} 7.2$. They were tested for clot dissolution potency at $37^{\circ} \mathrm{C}$. The results (Figure 4) show that the optimum $\mathrm{pH}$ of the reaction was between 6.5 and 7.5.

5. Effect of temperature on proteolytic activity: In order to test the effect of temperature on proteolytic activity, mixtures of identical amounts of microsomes and globulin were incubated for 30 min. at temperatures between 0 and $56^{\circ} \mathrm{C}$. At the end of the period of incubation they were transferred to a water bath at $37^{\circ} \mathrm{C}$. and the proteolytic activity estimated in the usual fashion. The results show that the optimum temperature was between $37^{\circ} \mathrm{C}$. and $44^{\circ} \mathrm{C}$. at $\mathrm{pH} 7.2$ (Table V).

TABLE $v$

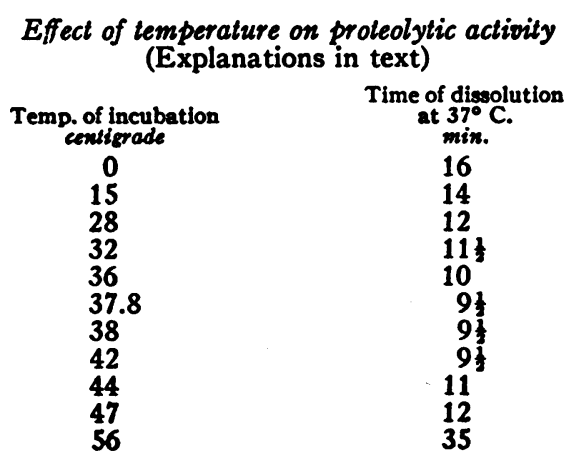

\section{DISCUSSION}

The data show that incubation of a cytoplasm suspension of rat lung with a plasma globulin fraction containing plasminogen resulted in the production of fibrinolytic activity. Fibrinolysis is due to proteolytic activity as has been shown repeatedly (2). The extract alone had no fibrinolytic activity during the period of observation but occasionally, as reported elsewhere by Tagnon and Petermann (7), it exhibited such activity after 16 to 24 hours of contact with fibrinogen. This may have been due to slight contamination of the fibrinogen solution with plasminogen.

The production of proteolytic activity by the addition of lung extract to a globulin solution containing plasminogen was interpreted as indicating probably that the extract contained a factor which activated plasminogen into plasmin. However, the data show that the extract probably contained, also, an inhibitor of the reaction. The fractionation of the extract by differential centrifugation was made with the hope that this might produce a fraction devoid of inhibitor. The data show that such a fraction could be prepared; the activator was found to be associated with the particulate component of the extract, while the inhibitor was in the supernate.

The data do not indicate clearly to which of the two particulate fractions the active principle is bound. However, it should be pointed out that the separation by differential centrifugation of mitochondria and microsomes from lung homogenates could not be considered satisfactory. This was due to the fact that the mitochondria of the various lung cells are small and break easily into fine granules. Accordingly, the difference in weight between them and the microsomes is reduced. Another unfavorable condition is the high viscosity of the lung homogenates due to the presence of mucus and fundamental substance. Under such conditions a certain amount of contamination of a fraction by the other, especially of microsomes by mitochondria, cannot be avoided. In view of this fact, no conclusion can be derived from the data presented here as to the exact localization of the active principle in the two fractions. However, one can say that in the experiments reported here, the active principle was invariably as- 
sociated with the particulate components of the lung extract and the microsomes were in all instances devoid of inhibitory effect. This fraction was, therefore, selected for subsequent studies of the activator present in the lung extract.

The globulin solution used in these experiments did not produce fibrinolysis when incubated with the standard amount of fibrinogen at $37^{\circ} \mathrm{C}$. for at least four hours and the addition of microsomes appeared, therefore, to be responsible for the rapid fibrinolysis observed in the experiments reported here.

The activator was found to be non-diffusible and, therefore, in this form not dialysable.

The properties of the material present in the particulate component of the lung extract are compatible with the hypothesis that this material is a kinase which activates plasminogen into plasmin through enzymatic action.

The distribution of the activator in different tissues is not the subject of this paper. Preliminary experiments to be reported elsewhere indicate that tissues may differ markedly in their content of activator. For instance, little or no activity was found in the fractions obtained from liver tissue and also from a rat fibrosarcoma.

The possible significance of the presence in certain tissues of an activator capable of activating plasminogen into plasmin may be briefly discussed:

1. The mechanism of the occurrence of fibrinolysis in shock and other pathological conditions has never been satisfactorily explained. It is conceivable that the activator present in certain tissues of the body may be released in the blood stream under certain conditions thus activating the plasma plasminogen. No experimental evidence is available at present to confirm this hypothesis.

2. The fact that the activator is found in the microsome fraction of lung tissue is of interest because the microsome fraction of lung contains also most of the thromboplastic activity of lung extract (8). On the other hand, extracts and microsomes from liver tissue are deficient in both activator and thromboplastin (11). This suggests a possible association of the two activities in tissue and fractions of tissue. It is not contended here that thromboplastin and activator are identical.
Before such an association is accepted as a fact, many more tissues will have to be tested.

3. The presence of an activator in tissue may provide the mechanism by which blood clots formed in tissues are eventually resorbed. The formation of a clot in tissue involves contact between the blood serum of the clot (containing plasminogen) and "tissue juice" (containing the activator) and realizes conditions favorable for the activation of plasminogen and removal of the fibrin of the clot by fibrinolysis.

4. The system described here consists of a proteolytic enzyme which is found in an inactive form in the circulating blood while the activator capable of activating it is extravascular. In this system activation of the enzyme will occur only if contact is established between intravascular and intracellular areas. In this respect this system is somewhat similar to the blood coagulation system, in which thromboplastin is extravascular also while the other participants in the reaction are found in the circulating blood. In this coagulation system also, the reaction will take place when the intra- and extravascular areas are brought into contact.

5. Plasminogen in blood plasma or serum samples cannot be measured directly but has to be first activated into plasmin. The existence of a tissue activator which can be easily prepared should provide the means by which the amount of plasminogen in a given sample of blood plasma can be measured.

\section{SUMMARY}

A cytoplasm suspension of lung tissue from rats was found to be able to activate plasminogen into plasmin. The activity of the extract resided in the particulate component of the extract. The microsome fraction of the extract had good activity and was completely free of the inhibitory action which was observed when the extract was used. The inhibitor was found to be concentrated in the supernate of the microsomes.

The properties of the activator of plasminogen present in the microsome fraction of lung tissue were considered to be compatible with the hypothesis that the activator is a kinase acting on the substrate plasminogen to transform it into plasmin. 


\section{BIBLIOGRAPHY}

1. Tagnon, H. J., Davidson, C. S., and Taylor, F. H. L., Studies on blood coagulation: a proteolytic enzyme prepared from calcium and platelet free normal human blood plasma. J. Clin. Invest., 1942, 21, 525.

2. Christensen, L. R., Streptococcal fibrinolysis: a proteolytic reaction due to a serum enzyme activated by streptococcal fibrinolysin. Gen. Physiol., 1945, 28, 363.

3. Tagnon, H. J., Levenson, S. M., Davidson, C. S., and Taylor, F. H. L., The occurrence of fibrinolysis in shock, with observations on the prothrombin time and the plasma fibrinogen during hemorrhagic shock. Am. J. M. Sc., 1946, 211, 88.

4. Seegers, W. H., Nieft, M., and Loomis, E. C., Note on the adsorption of thrombin on fibrin. Science, 1945, 101, 520.

5. Astrup, T., and Permin, P. M., Fibrinolysis in animal organism. Nature, 1947, 159, 681.
6. Astrup, T., Fibrinolytic enzymes, in: Transactions of the First Conference on Blood Clotting and Allied Problems. Josiah Macy, Jr. Foundation, New York, 1948, p. 28.

7. Tagnon, H. J., and Petermann, M. L., Activation of proplasmin by a tissue fraction. Proc. Soc. Exper. Biol. \& Med., 1949, 70, 359.

8. Claude, A., Fractionation of mammalian liver cells by differential centrifugation. II. Experimental procedures and results. J. Exper. Med., 1946, 84, 61.

9. Hogeboom, G. H., Schneider, W. C., and Palade, G. E., Isolation of morphologically intact mitochondria from rat liver. Proc. Soc. Exper. Biol. \& Med., 1947, 65, 320.

10. Ware, A. G., Guest, M. M., and Seegers, W. H., Fibrinogen: with special reference to its preparation and certain properties of the product. Arch. Biochem., 1947, 13, 231. 